\title{
Grape and wine culture in Georgia, the South Caucasus
}

\author{
David Maghradze ${ }^{1, \text { a }}$, Giorgi Samanishvili ${ }^{1}$, Levan Mekhuzla ${ }^{1}$, Irma Mdinaradze ${ }^{1}$, George Tevzadze ${ }^{1}$, Andro Aslanishvili ${ }^{1}$, \\ Paata Chavchanidze $^{1}$, David Lordkipanidze ${ }^{2}$, Mindia Jalabadze $^{2}$, Eliso Kvavadze ${ }^{2}$, Nana Rusishvili ${ }^{2}$, Eldar Nadiradze $^{2}$, \\ Gvantsa Archvadze ${ }^{2}$, Patrick McGovern ${ }^{3}$, Patrice This ${ }^{4}$, Roberto Bacilieri' ${ }^{4}$, Osvaldo Failla ${ }^{5}$, Gabriele Cola ${ }^{5}$, \\ Luigi Mariani $^{5}$, Nathan Wales ${ }^{6}$, M. Thomas P. Gilbert ${ }^{6}$, Laurent Bouby ${ }^{7}$, Tina Kazeli ${ }^{8}$, Levan Ujmajuridze ${ }^{9}$, \\ Stephen Batiuk ${ }^{10}$, Andrew Graham ${ }^{10}$, Lika Megrelidze ${ }^{11}$, Tamar Bagratia ${ }^{11}$, and Levan Davitashvili ${ }^{12}$ \\ ${ }^{1}$ National Wine Agency of Georgia, 6 Marshal Geloveni Ave., 0159 Tbilisi, Georgia \\ ${ }^{2}$ National Museum of Georgia, 3 Purtseladze Str., 0105 Tbilisi, Georgia \\ ${ }^{3}$ University of Pennsylvania Museum of Archaeology and Anthropology, 3260 South St., Philadelphia, PA 19104, USA \\ ${ }^{4}$ INRA-CIRAD-SupAgro, UMR AGAP, 1334 Montpellier, France \\ ${ }^{5}$ University of Milan, via Celoria 2, 20133 Milano, Italy \\ ${ }^{6}$ University of Copenhagen, Øster Voldgade 5-7, 1350 Copenhagen, Denmark \\ ${ }^{7}$ Institut des Sciences de l'Evolution, University of Montpellier, Place Eugène Bataillon, 22, 34095 Montpellier, France \\ ${ }^{8}$ Georgian Wine Association, 12 Mtatsminda Str., 0108 Tbilisi, Georgia \\ ${ }^{9}$ Scientific - Research Center of Agriculture, 6 Marshal Geloveni Ave., 0159 Tbilisi, Georgia \\ ${ }^{10}$ University of Toronto, Dept. of Near \& Middle Eastern Civilizations, 4 Bancroft Ave, Toronto, Canada \\ ${ }^{11}$ Environmental Agency of Georgia, David Aghmashenebely Ave., 0112 Tbilisi, Georgia \\ ${ }^{12}$ Minister of Agriculture of Georgia, Tbilisi, Georgia
}

\begin{abstract}
In 2014, the National Wine Agency of the Republic of Georgia initiated a three-year "Research Project for the study of Georgian Grapes and Wine Culture. Through collaborative research by Georgian and foreign institutions and researchers, the project aims to: stimulate research of Georgian viticulture and viniculture, through the lens of the country with the earliest tradition of grape domestication and winemaking; and to reconstruct the continuous development of viticulture and wine culture through time. The project advances the study of grape and wine culture by utilizing a multidisciplinary approach, including: archaeology, history, ethnography, molecular genetics, biomolecular archaeology, palaeobotany, ampelography, enology, climatology and other scientific fields. These studies are diachronic in their approach, beginning with the oldest Neolithic civilizations, to present day, creating a holistic understanding of the continuity and complexity of Georgian Wine Culture to help popularize Georgian Wine throughout the global wine market.
\end{abstract}

\section{Introduction}

The Republic of Georgia, a small country of the South Caucasus, located between Black and Caspian Seas, has a long and ample history of viticulture and winemaking.

The first domestication of grapevine (Vitis vinifera ssp. sativa) took place from its wild ancestor Vitis vinifera ssp silvestris probably in the Caucasian area [1] and the most ancient evidence of wine making activities date back to the Neolithic period in the mountainous region of the Near East, including the Caucasus, the eastern Taurus, and the northwestern Zagros where the earliest chemically attested wine jar discovered to date at Hajji Firuz Tepe, is located [2]. In the Caucasus, no indication of cultivation is currently available before the 6th -5 th millennia BP; after which, carbonized pips, berries, pollen and wood remains are more frequently reported from sites located well outside the indigenous distribution area of Vitis sylvestris $[3,4]$.

In this context, a valuable contribution can be obtained from paleoclimatology, because grapevine domestication and its expansion was carried out in the context of the

\footnotetext{
${ }^{a}$ Corresponding author: david.maghradzer@georgianwine. gov.ge
}

relevant variability of the Holocene climate [5,6] which imposed strong limitations to the grapevine distribution zone.

Investigations into the history of the modern grapevine began in the 1960s, with the discovery in the territory of modern South Georgia, Northern Armenia and Western Azerbaijan of one of the earliest cultures of the South Caucasus, known as "Shulaveri-Shomu Tepe Culture dated between $6.000-4.000$ BCE (Fig. 1) [7-9]. This archaeological culture is identified through its mudbrick architecture, ceramics, stone and bone tools, and advanced agriculture with the cultivation of several crops, among which it has been considered grapes - suggested by the discovery of a motif of four stylized grape bunches that somewhat frequently appears on the walls of clay jar, best exemplified by the example uncovered at "Khramis Didi Gora", now on exhibit in the Georgian National Museum (Fig. 2) [10-12]. This period can also be considered to be a starting point for Neolithic wine production based on a preliminary study by McGovern [2], when he reported possible traces of tartaric acid - the main biomarker for grapes and its byproducts (e.g., wine), in one of the Neolithic jars from "Shulaveris Gora" (see below). 


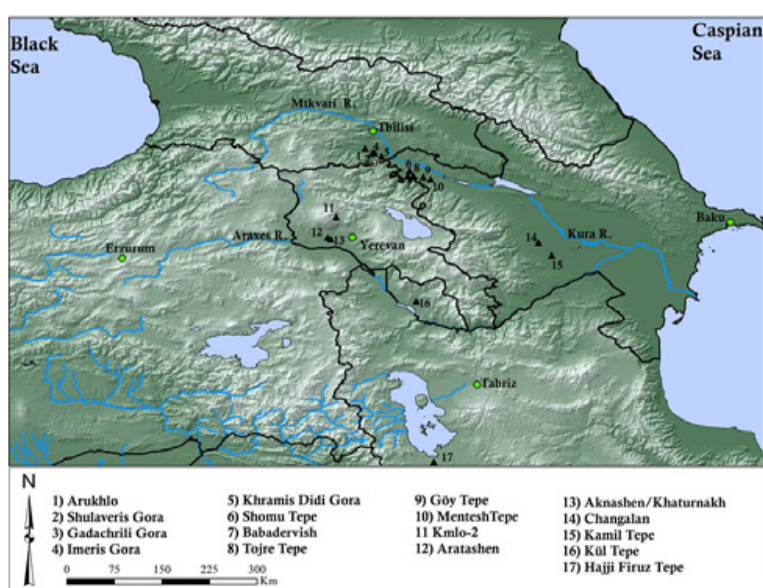

Figure 1. Map with the principal sites that preoduce the Neolithic 'Shulaveris-Shomu Culture', and Hajji Firuz in Iran which to date has the earliest definitive chemical evidence of ancient wine.

Following the "Shulaveri-Shomu Culture", the "Mtkvari (Kura)-Araxes culture" - also known as the "Early Trascaucasian Culture", ETC - (circa 4000-2000 BCE) emerged in Southern Caucasus and then spread across the Near East, along with a further development of livestock breeding, bronze metallurgy, and farming practices [13]. Multiple lines of evidence, including settlement patterns, ceramic analysis and textual records, along with the long recorded history in South Caucasia (commonly regarded as the place of origin of the ETC), are used to postulate an economic niche for the ETC in viti- and viniculture, which results in the spread of wine consumption across the Near East [14].

The "Trialeti culture", emerged in the first part of the 2nd millennium BC and reached its peak in 1500 BC in Eastern Georgia. Large burial mounds ('Kurgans') found at the site of Trialeti itself and other sites of the period have yielded marvelously ornate gold and silver goblets, often depicting drinking scenes or ceremonies, highlighting the importance of the vine to this culture [15].

In Western Georgia, a new and unique culture known as Colchian developed between 1300 and 700 BCE. According to Herodotus ( $5^{\text {th }}$ cent. BCE) and Strabo $\left(1^{\text {st }}\right.$ cent. BCE), winemaking prospered in the region: the "fizzing and sweet-as-honey wine of Colchis" are frequently mentioned in their works. The discovery of grapevine seeds from the settlement of Ergeta (Zugdidi district, VII-VI cc. BCE) and Gienos (Ochamchire district, VII-VI cc. BCE) belonging to V. vinifera ssp. sativa and to $V$. vinifera ssp. sylvestris [4] as well as other archaeological artefacts linked to viticulture and wine makings appear [16].

Viticulture and winemaking held a preeminent position during the Christian Age ( $4^{\text {th }}$ to $9^{\text {th }}$ centuries CE). St. Nino preached Christianity with a cross of grapevine canes and the "Grapevine Cross", becomes a major symbol of the Georgian Orthodox Church by 337, when Christianity became the official religion of the Georgian Kingdom of Iberia. By the Medieval period ( $10^{\text {th }}$ to $15^{\text {th }}$ centuries CE) we have: "Marani" (wine cellars) with clay jars "Qvevri" and "Satsnakheli" (presses), as well as viticultural tools, fossilized grape seeds, and signs of irrigation systems and terraces for the cultivation of grapevine found all over Georgia. Additionally, imagery of grapes and grape vines proliferate and become a main Church ornament across Georgia [16]. Because of the identification of 525 varieties on grape in the region [17], as well as several original technologies for winemaking [18], such as making of wine in Qvevri jars, Georgian Wine was been recognized as an UNESCO Intelligible Heredity in 2013.

Since the beginning of the $19^{\text {th }}$ century until the 1990's, Georgia was integrated in the Russian Empire and subsequently the Soviet Union, which resulted in a new and wide market for Georgian wines. Construction of new wineries began, the planted area of vineyards was expanded which gave a new impulse to the winemaking sector $[17,19,20]$. The 21 st century started with various conditions of economic rise and crises which influenced the development wine sector of the Georgia.

The long history of grape growing and wine making activities had deep and significant influence on various aspects of economic and social life in Georgia; such as diet, architecture, music, art, literature, science, etc. [21]. We can say that the grape and wine became central to the identity of the Georgian nation.

Taking in note the importance of viticulture and winemaking for the country, the National Wine Agency of the Republic of Georgia initiated a three-year "Research Project for the study of Georgian Grapes and Wine Culture" in February 2014. Through collaborative research by Georgian and foreign institutions with researchers from the USA, Italy, France, Canada, Denmark, Israel, the project aims to develop research activities in a variety of research areas such as: new archaeological excavation of Neolithic settlements; the systematization analyses of and radiocarbon dating of the grape remains discovered on the territory of Georgia from various historical epochs; biochemical testing of archaeological artifacts for the purposes to discovery tartaric acid"s and other chemical compounds as markers for Vitis vinifera wines; the characterization of soil and agro climatic features of Georgia with regards to viticultural and winemaking practices, including the reconstruction of past "Holocene" climate; the study of ancient DNA from grape seeds from archaeological contexts for the purposes of their comparison to the modern DNA of the grape gene pool (varietal and wild grapevine); the presentation of enological and ethnographic heredity of Georgian viticulture and winemaking; and the analyses of modern fields of viticulture and winemaking for the purposes of their evaluation and argumentation in the historical background. The project aims to advance the study of grape and wine culture of Georgia by utilizing a multidisciplinary approach to help popularize Georgian wine throughout the global wine market

The aim of this paper is to provide basic information about this project and its main results to wide audience of researchers and policy-makers of the vini-viticultural sector, as well as to provide evidences of the rich culture of grape cultivation and wine making in Georgia.

\section{Materials and methods}

\subsection{Structure}

The project is organised into a system of five Working Groups: 1) Archaeology and History; 2) Ancient and modern DNA; 3) Biomolecular archaeology; 4) Georgian 
viticulture and winemaking; 5) Dissemination and public awareness. The scientific supervisor of the project is Prof. D. Lordkipanidze - Director of the National Museum of Georgia. The project started in January, 2014.

\subsection{Archaeology and history}

\subsubsection{Archaeology}

Recently excavations have been renewed at the Neolithic settlements of Gadachrili Gora and Shulaveris Gora located in the district of Marneuli, in Lower Kartli province [9]. These sites are a cluster of agricultural settlements that were populated by people known as being part of the "Shulaveri-Shomu Tepe" culture (6th Millennium BCE).

The purpose of these excavations is threefold; to provide a rich dataset of archaeological samples originating from the by-products of wine production and consumption during the Neolithic; to preserve and conserve excavated materials for site consolidation and presentation to the public; and to provide cross-cultural educational opportunities for local (Georgian) and foreign (Canadian) undergraduate students of archaeology.

As a result of these most recent efforts, $270 \mathrm{~m}^{2}$ was excavated just in 2016 at Gadachrili Gora, including two major phases of occupation, and a small $1 \times 5 \mathrm{~m}$ step trench and a section cleaning at Shulaveris Gora, which identified six layers of occupation, all dated to the Neolithic period. Amongst the well preserved remains include circular mud-brick architecture, which are typical of the culture. These efforts have been successful in providing a more expanded context with which to evaluate recovered samples. These samples consist of pottery (ceramic), lithic (stone tools), faunal (animal bone), paleobotanical (plants/seeds) and geological (soil) materials recovered from anthropogenic contexts revealed through careful excavation. The study and analysis of all these samples constitute the next phase of the biomolecular archaeological investigation. In addition, the paleobotanical samples have provided good materials for radiocarbon dating.

In conjunction with the archaeological excavations a program of architectural conservation activities has been initiated at "Gadachrili Gora" along with the development of a plan for an "Archeological park / museum" project for preservation and presentation of the "Shulaveri-Shomu culture" in the region.

\subsubsection{Archaeobotany}

Carbonized plant remains were collected by floatation sampling for further laboratory archaeobotanical and paleobotanical analysis and radiocarbon dating (N. Rusishvili, E. Kvavadze).

The samples were collected from the previously discussed two sites of "Gadachrili and Shulaveris Gora", as well as "Treligorebi" (village Dighomi, close to Tbilisi, the $4^{\text {th }}-2^{\text {nd }}$ centuries BCE), "Kapnistavi" (Khelvachauri district, early Middle Ages) and "Dekhviri" (Tsageri district, late Middle Ages).

The examinations of archaeological and modern seeds included: i) Twenty six samples of grape seeds from the National Museum of Georgia, discovered during various archaeological excavation over the past sixty years, were analyzed by radiocarbon $\mathrm{C} 14$ dating in the D-REAMS laboratory of Weizman Institute, Israel (supervisor E. Buaretto); ii) the examination of wood samples for speciation by the paleobotanists N. Miller at the University of Pennsylvania (USA) and L. Bouby.

\section{Morphometry of ancient seeds}

It was selected and the photography was captured for the archaeological seeds with the idea of their verification to modern seeds of Georgian and European varieties and wild grapes studded by the "Morphogeometric analyses" leaded by L. Bouby.

We are utilizing morphometric geometrics to characterize archaeological grape seeds in comparison to modern wild and domesticated grape samples. Our goal is to identify ancient seeds of the wild and domesticated types and compare these to modern cultivars from the Caucasus region and other areas across Europe and the Mediterranean world. The morphogeometric approach we are using is based on the elliptic Fourier transform analysis of dorsal and lateral seed outlines [22,23]. First we have inventoried the available samples of archaeological Vitis seeds and confirmed the chronology of most of them using radiocarbon dating of individual seeds.

\subsubsection{Paleobotany}

More than 100 samples were studied palynologically from the settlement of "Gadachrili Gora" ( $6^{\text {th }}$ Millennium BC) during 2007-2015, obtained from 8 vessels, 9 farm pits, 6 repositories and 15 cultural layers.

\subsection{DNA study}

\subsubsection{Modern DNA}

A set of 41 cultivated and 77 wild grapes of Georgian origins were studied with DNA technologies and compared to a larger dataset available at INRA [24]. First, we carried out microsatellite (SSR) fingerprinting with the nine SSR used in the EU-Vitis database, so to check identities, possible synonyms, homonyms and misnomers, as well as parentages. Once the list of original genotypes was confirmed, we used a hybridization capture kit, defined by INRA and GeoGenetics to capture and sequence stretches of DNA corresponding to around 10.000 known DNA variations in grape (Single Nucleotide Variaton, or SNP). We also added to the sample 12 Asian Vitis and one Muscadinia species as outgroups.

\subsubsection{Ancient $D N A$}

A protocol for extraction of archeological plant remains for further study of ancient DNA was elaborated by the laboratory of "GeoGenetics" at the University of Copenhagen, Danmark (Supervisor T. Gilbert) and tasted by the National Museum of Georgia during archaeological expeditions.

A collection of 19 archaeological Vitis seeds and 2 ancient branches were processed using state-of-theart techniques at the paleogenomics laboratory at the University of Copenhagen. Samples ranged in age from $4000 \mathrm{BC}$ to $1750 \mathrm{AD}$, spanning many important stages in early grapevine cultivation and the historic era. DNA isolated from specimens was converted to Illumina 
libraries for Next Generation Sequencing, and shotgun sequencing was performed. The origin of DNA in specimens was examined using NCBI's BLAST database, quantifying relative proportions of Vitis, bacterial, and fungal DNA. Samples exhibiting high levels of grape DNA were enriched for nuclear SNPs as described above for modern accessions.

\subsection{Biomolecular archaeology}

Twenty-two pottery sherds with seven corresponding soils samples from Neolithic Shulaveri culture Georgia were analysed for possible grape/wine residues in 2014 and 2015. The sites included "Gadachrili Gora," "Shulaveri Gora," and "Arukhlo," which was excavated under the auspices of Dr. Sved Hansen (Germany) and Dr. Guram Pirtskhalava (Georgia). Dr. Patrick E. McGovern of the Biomolecular Archaeology Project of the University of Pennsylvania Museum headed the project, in collaboration with Dr. Gretchen R. Hall of the Penn lab, Dr. W. Christian Petersen of the Winterthur Museum's Museum Conservation Laboratory, and Dr. Michael P. Callahan and Dr. Karen E. Smith of NASA's Goddard Space Flight Center.

The project enabled us to develop a new, sensitive approach to identifying all the main organic acids in wine, viz. tartaric, malic, citrus, and succinic. Further extraction refinements in our Gas Chromatography - Mass Spectrometry (GC-MS), Fourier-transform Infrared Spectrometry (FT-IR) and Orbitrap Liquid Chromatography Tandem Mass Spectrometric (LC/MS/MS) analyses were also made.

After macroscopic and low-power microscopic examination and photographing, the sherds were sampled for any potential interior residues and other characteristics of interest. Samples were divided up for analysis by FT-IR and GC-MS separately from those for LC/MS/MS with a linear ion trap-Orbitrap detector (Orbitrap LC/MS/MS).

1) Extraction: For FT-IR and GC-MS, the interior surfaces of the sherds were ground down to a depth of 1-3 mm after removing any glue and extraneous soil with distilled water. The powdered residues and accompanying soils were then further ground down by an agate mortar and pestle, as needed, and extracted by our standard chloroform/methanol procedure by boiling in glassware for $3 \mathrm{hr}$., combining the solutions, and evaporating to dryness.

2) FT-IR analyses, databases and searches: The FTIR data were obtained on Thermo Nicolet spectrometers by diffuse-reflectance on samples mixed with $\mathrm{KBr}$ or on neat (unmixed) samples run using a diamond cell. The FT-IR spectra were searched for "matches" against large databases of relevant natural products and processed organic materials, synthetic compounds, modern wine samples, and "ancient wine reference samples". The latter are residues from ancient vessels which likely originally contained wine, based on strong archaeological criteria or exterior inscriptions which recorded their contents. Samples of special interest are those that provide matches to ancient and modern wine samples, to a high level of probability ( 90 or above on a scale of 100 , according to Thermo Scientific's proprietary OMNIC algorithm).

3) GC-MS analyses, databases and searches: For our experimental methodology in running GC-MS analyses, see McGovern et al. [25] and McGovern et al. [26]. Compound identification was made by retention time and mass spectrum using NIST 05.

4) Orbitrap LC/MS/MS extractions and analyses. For our experimental methodology in running LC/MS/MS analyses, see McGovern et al. [26]. Tartaric acid, malic acid, succinic acid, and citric acid in the sample extracts are identified by (a) correlating sample compounds with known standards at the experimentally determined chromatographic retention times and (b) comparing accurate mass measurements with theoretical exact masses for the organic acids. Elemental compositions are calculated from the deprotonated molecule with introduced limits of carbon (0-30), hydrogen (0-60), nitrogen (0-10), and oxygen $(0-15)$, with a mass tolerance of $2 \mathrm{ppm}$. Peak areas are obtained by either manual integration or by the ICIS peak algorithm in the Xcalibur software package.

5) Bioinformatics evaluation. A bioinformatics approach was key to identifying grape/wine and other natural products which may have been further processed by humans. Biomarkers should be specific to a given geographic area.

\subsection{Viticulture and winemaking}

\subsubsection{Agroclimatology for viticulture}

All biological cycles are driven by environmental variables. For this reason it is very important to analyze and characterize viticultural areas in terms of environmental resources and limitations for grapevine development and production taking into account climate variability and change.

About this matter, while the climate of Western Europe has been deeply affected by the abrupt climate change that took place in the late ' 80 s of the 20 th century [27, 28], a similar signal was detected for Georgia only few years later, in 1994. In fact the current climatic phase (1994-2013) shows an increase of $1.4^{\circ} \mathrm{C}$ in yearly temperature when compared with the previous phase (1974-1993).

For this reason it was particularly interesting to evaluate how deeply grapevine phenology was influenced by the climate of 1994 .

In order to evaluate the effects of climate change on grapevine phenology, the availability of thermal resources in the two climatic phases for five altitudinal belts in the $0-1250 \mathrm{~m}$ range was analyzed.

Furthermore, a phenological model for Georgian varieties was calibrated on the base of phenological data collected in the two experimental sites of Koshkebi and Saguramo during 2012-2014 [29,30]. The model based on the Normal Heating Hours (NHH) approach [31], is able to predict $\mathrm{BBCH}$ phenological stages 61 (beginning of flowering), 71 (fruit set) and 81 (veraison) for four relevant Georgian varieties (Mtsvane Kakhuri, Rkatsiteli, Ojaleshi and Saperavi). The model, was validated on an independent three year dataset (2004-2006) gathered in Gorizia, Italy [32].

\subsubsection{Ancient climate reconstruction}

The present altitudinal limit of Vitis vinifera in West Georgia is about $500-800 \mathrm{~m}$ asl depending on morphological features like slope and aspect that influence solar radiation 
and temperature. Incidentally this limit is coherent with limits of thermophilous taxa like Zelkova carpinifolia Pall. and Castanea sativa $\mathrm{L}$.

In the light of this we have adopted the tree line defined by Connor and Kvavadze [33] for Abkhazia region as a proxy of the altitudinal limit of wild and domestic grapevine (Vitis vinifera L.) in West Georgia. So, applying a coefficient of correction of $-1100 /-1300 \mathrm{~m}$, we have obtained the Holocene evolution of altitudinal limit of grapevine (Figs. 4, 5) for the whole country.

\subsubsection{Ethnography}

National Museum of Georgia collected archaeological and ethnographic data linked to the viticulture and winemaking of the country on the web-site of the project to use those for "Archaeological Catalogue" and "Ethnographic Catalogue" for their systematization, research and further usage in the project activities.

\subsubsection{Ampelography: Cultivars and wild grape}

For the purposes to study the DNA of modern grape gene pool (Georgian local varieties and wild grape), 41 cultivar and 76 wild varieties were collected.

To investigate the wild grape Vitis vinifera ssp. silvestris an ancestor of cultivated grape, several expeditions were organized for its investigation in their natural ecosystems within the country. The discovered plants were described by ampelographic and GPS methods. The mature woody canes were collected for DNA study and for further propagation within a field repository established in the village of Jighaura in 2015 belonging to the Scientific - Research Center of Agriculture.

\subsection{Dissemination and public awareness}

Holding various public events and preparation of publications for demonstration and dissemination the obtained results of various aspects of Georgian grape and wine culture both inside the country as well for the international society is one of the objectives of the project.

In this vein, the National Wine Agency has published several scientific and popular publication in the framework of the project.

The information about our project's activities has been systematically provided to a wide audience by public demonstration days, as well as television and radio broadcasts.

\section{Results and discussions}

\subsection{Archaeology and history group}

New archaeological excavations of the early Neolithic agricultural settlments of "Gadachrili Gora" and "Shulaveris Gora", belonging to the "Shulaveri - Shomu Tepe Culture" of South Caucasia (the 6-5 ${ }^{\text {th }}$ Millennium BC) discovered new artefacts possibly linked to viticultural and winemaking activities - specifically ceramic wares.

The project aims to identify, collate and synthesize the currently available archaeological artifacts associated with viti- and viniculture into an "Archaeological Catalogue". Additionally, a robust chronology of the history of Georgian viniculture is also being reconstructed through

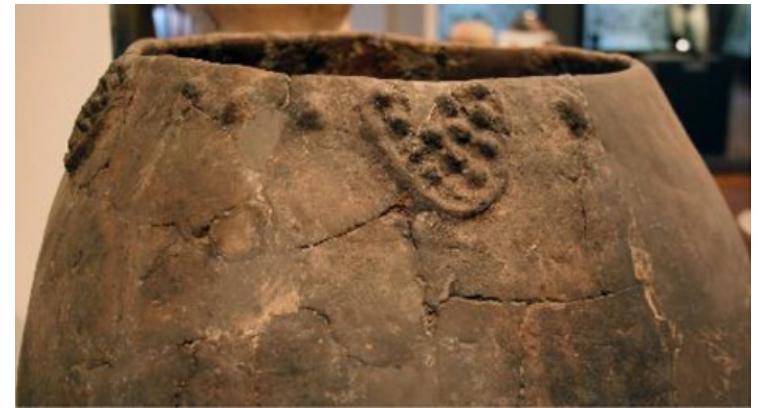

Figure 2. Clay store jar from the excavations of 'Khramis Didi Gora', in the Georgian National Museum.

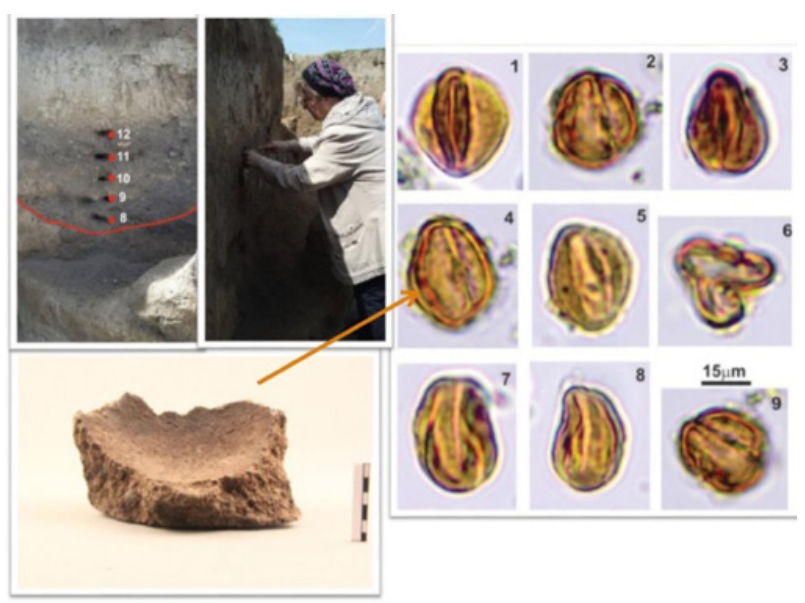

Figure 3. Palynological sampling from Gadachrili Gora and grape pollen identified from vessel base discovered in excavations.

systematic radiocarbon analyses and dating the grape remains (seeds, wood) and artifacts linked with wine making from across a wide variety of Georgian historical periods.

The presence of the oldest grape pollen has been identified in the deposits of buildings, storage pits and on the walls of the buildings from the site of "Gadachrili Gora"; and grape pollen and seeds have been identified at the site of "Treligorebi" as well. Carbonized seeds of other crops such as wheat, barley, bitter vetch, lentil, pea and additional weeds associated with agriculture were also discovered at "Gadachrili Gora", confirm the presence of agriculture in Lower Kartli 8.000 years ago.

Seed Morphometry. Presently we have been able to analyze 457 Vitis seeds from archaeological contexts, originating from 11 Georgian sites dating from the Early Bronze Age to Modern times. The domesticated morphotype is identified from the Iron Age onwards and is generally predominating in all the archaeological samples. There is a strong diversity of domesticated shapes in the samples. These types are close to modern cultivars from various geographical origins, especially from the Caucasian region and from Greece.

Paleobotanical research. The results of study of "Gadachrili Gora" samples demonstrates that $80 \%$ of those contains pollen grains of common vine Vitis vinifera L., as well as pollen of weeds characteristic of a vineyard.

The palynological spectra content of the pottery, strongly suggest the existence of wine in them, which are of special interest. The use of the palynological 
analysis for identification of wine residue in archeological vessels has just started to successfully be realized [34-36]. An international program of pollen monitoring (Pollen Monitoring Programme) implemented in England and Georgia [35,37-39], has significantly aided this investigation. Monitoring has shown that productivity of the Rkatsiteli cultivar pollen grains increases in a good climate conditions in Kakheti, i.e. when there are no drought and frosty winters there. More than 50000 pollen grains of vine are accumulated in soil on $1 \mathrm{~cm}^{2}$ under the vine per year. Significant pollen is deposited on leaves and grapes of vine, which get into pressed wine. The experiment has shown that about one thousand pollen grains get into the wine pressed in domestic conditions in a fruitful year [35].

New research also reveals that apart from pollen grains, starch and epidermal cells are also good indicators for existence of wine. Microscopic hairs of insects are also always found in wine as well. These are the result of the insects which always whirl around the vine fruits or vessels full of wine.

In the pottery found in the repositories and household pits of "Gadachrili Gora", particularly in the bottoms of which are preserved, pollen grains of vine, vine starch, microscopic cells of vine cane and hairs of flies are found. Pollen grains of Vitis are also found on the floors of dwellings, and in all farm pits and repositories. These discoveries confirms that humans grew vines in Neolithic era.

The fact that the remains of grape (Vitis vinifera) flower have also been identified in occupational layers is of great interest as well. We suggest several arguments to explain its occurrence. Either vines (Vitis vinifera) were planted near the building identified by our excavations, or its flowers were specially picked and stored in the repositories and pits of dwelling. It is known that leaves, seeds and the juice of grapes possess numerous medicinal properties. Moreover, humans used grapes for food, and therefore it should have been an important part of the local diet, which is confirmed by the identification of pollen of vine (Vitis vinifera) and acetic acid found on the walls and bottom of pottery [36].

Palynological researches have also revealed existence of other horticulture cultivars, indicating walnut and other nut were grown and stored in repository pits. Production of wheat was also very developed as well, as the palynological and paleobotanic studies have revealed several species of wheat. Additionally there is evidence of growing flax, from which textiles could be spun by loom [40].

Considering the palynological results and paleoecological information obtained in recent years, in conjunction with palynology of materials of "Gadachrili Gora" and "Shulaveri Gora" $[35,36,40,41]$, it is possible to define that the landscape which would have been forested in antiquity. Evidence suggests forests of hornbeam and oriental hornbeam, as well as beech, oak, elm, zelkova, alder buckthorn, willow, box tree and juniper. Floodplain forests spread along the banks of rivers, where alder tree, willow and Caucasian wingnut (Pterocarya fraxinifolia) grew. Forest ferns should have been in present in significant amounts in these humid forests, as their spores are well present in nearly all palynological spectra of analyzed material. The following species of fern were identified - Polypodium vulgare, Asplenium, Dryopteris, Cryptograma crispa, andOphioglosum vulgatum. The spores of Lycopodium clavatum are found. These taxa, as well as alder and Caucasian wingnut, require humid climate conditions. Forests of pine, fir and spruce should have been spread on higher slopes of nearly mountain.

Taxonomic list of identified plants and ecology of these taxa confirm that the climate of the region should have been much more humid and warm in the Neolithic period. It should be noted, that today Zelkova and the Caucasian Wingnut grow only in the Alazani and Kolkheti valleys. The forest reserve of Babaneuri in Kakheti is the place where the forest of Zelkova of high bonitet has survived since the Tertiary period, and wingnut grows only in Lagodekhi reserve and on the banks of river Alazani [5,42-44]. The palynological spectra of the examined soil and mosses of the Alazani forest reveals that there are also significant forest fern spores, which correspond to the spectra found in the cultural layers of Gadachrili Gora. As a result, the following conclusions might be drawn: the climate conditions in Kvemo Kartli 8.000 years ago should have been similar as to todays in Alazani valley, where annual amount of precipitations is $700-800 \mathrm{~mm}$, and annual average temperature is $14^{\circ} \mathrm{C}-15^{\circ} \mathrm{C}$. Today in Kvemo Kartli where steppe landscapes prevail, annual sum of precipitations does not exceed $350-400 \mathrm{~mm}$, average annual temperature is lower than in Alazani valley and reaches $12^{\circ} \mathrm{C}-12,5^{\circ} \mathrm{C}$. It should be also noted that palynological spectra of steppe landscapes of study region is of a significantly different type, where the afore mentioned forest ferns, pollen grains of Zelkova and Caucasian wingnut are not found there at all [45].

\subsection{Ancient and modern DNA group}

The DNA analyses of ancient grape seeds and plant remains from Georgia was undertaken to evaluates and assesses the DNA of ancient varietals against modern Georgian and European wild and domesticated varieties, in an effort to examine the phylogeny and taxonomic relationships and to infer hypothesis about grape domestication and the spreading of its cultivation around the Mediterranean basin. The genetic information obtained will be merged with already existing ampelographic characterization and cultivation data of genetic resources so to inform their distribution and use in the global setting.

Among the preliminary results provided by this study we obtained evidence that: i) most of the Georgian wild grapes are true-to-type as related to their wild sub-species status; ii) while it is still difficult to assign recent or ancient varieties to a precise country of origin, and the work on this aspect is still in progress (with the objective to be published in a scientific journal) the data indicate that Georgia, in the context of the Caucasian region and with its links with Central Asian countries, was a major initial contributor to grape domestication. Even as importantly, its local wine tradition used and bred this original material to create new cultivars, then spreading them to the World.

A total of sixty five genotypes of Georgian grape (wild and cultivated) were characterized with usage of new SNPs markers by the Vitis18kSNP array by the University of Milan, Italy [46]. 
We tested 19 samples of grape seeds and wood specimens from nine archaeological sites from around Georgia. As a result it has become possible to extract the DNA of four samples from the sites of Tsitsamuri (14351475 BCE), Borjomi (1644-1666 BCE) and Samtavro (1736-1778 BCE), developing a DNA library. Further molecular work, including various aspects of genome sequencing and statistical analyses has been undertaken. The results obtained have been compared to the database of modern samples available in the "GeoGenetics" laboratory with idea to check genetic relationship between old and new varieties, which have been successfully identified for some accessions.

\subsection{Biomolecular archaeology group}

The chemical detection of tartaric and other organic acids, which are markers of the Eurasian grape (Vitis vinifera) and its products, inside ancient vessels is crucial in establishing the original presence of wine in the vessels. The additional detection of other chemical compounds from botanicals and tree resins, such as diterpenoids and triterpenoids, are used to determine specific winemaking practices in the past, which distinguish the product as most likely wine.

The most notable result from the project to date is a more detailed analysis of Shulaveris-Goris 16a in conjunction with analyses of other Neolithic vessels. This is the sherd, which P. McGovern suggested was positive for tartaric acid (TA) many years ago [2] based on less exact methods, and which the media claimed as "proving" that the earliest wine came from Georgia. He cautioned that it was only one sample and more analyses and better methods were needed to be sure. This project has made that possible, and so far, we have another sherd from Gadachrili Gora (II-9) which appears to be positive for TA by Orbitrap LC/MS/MS. Its TA content is nearly an order of magnitude (10X) than the background soil from the site. Except for succinic acid, it's malic and citric acid contents-all acids associated with TA in grape/wine-were above the background soil contents.

Another sample (GG II-3) was marginally higher in TA, and the contents for the other acids were below or equal to the soil contents. Shulaveris-Goris 16a has now been shown to be "borderline positive". This may be a result of not yet having obtained actual background soil samples from Shulaveris-Goris to compare with the results from the sherd, but rather relying on those from Gadachrili Gora. We did this, because no Shulaveris-Goris samples were available and as a stopgap measure since geological maps show that Grey Cinnamonic Dark soil zone extends across both sites. But there could be differences in the microorganism populations at each site.

Shulaveris-Goris 782 was negative for TA, using the Gadachrili Gora soils as background. That assignment could change if soil samples from Shulaveris-Goris are used.

The new Phase III analyses in 2016 should definitively establish whether grape wine was being produced in Neolithic Georgia. If so, it will push back the date for the earliest wine production in the Near East some 1500 years (Hajji Firuz, Iran has held this distinction since the publication of McGovern, et al. [47].

\subsection{Georgian viticulture and winemaking group}

\subsubsection{Agroclimatology for viticulture}

This workgroup created a more holistic agronomic understanding of wine production in Georgia and how it might have changed over the millennia. Furthermore, by collecting soil aptitude descriptions and developing a study collection of the wild grapevine Vitis vinifera sylvestris from of the various regions in Georgia, and analyzing modern vineyards and winemaking practices, they will evaluate viti- and viniculture's role within the larger historical context of Georgian society and culture. Through the collection of modern and proxy environmental data, a characterization of the past as well as modern climatic patterns of Georgia is being established and mapped to reconstruct past climate patterns with an eye towards modern climate change and how it may affect Georgian viticulture.

After statistical elaboration of obtained climatic data and the development of agro climatic maps was undertaken, analyses of changing climate patterns in Georgia could be undertaken; calculating of agro climatic indexes for viticulture; characterization of viticultural regions according to location of the vineyards, soil and agro climatic parameters.

With reference to the development of phenological models for Georgian varieties ad to the analysis of how grpaveine phenology was affected by climate change,

The model performance in terms of prediction was quite satisfactory, with a Mean Absolute Error of 3.8 days in calibration and 3.2 in validation [48].

In the case of the Rkatsiteli variety, the model was applied to the 1974-2013 thermal daily fields in order to obtain phenological maps of the Georgian territory for the two climatic phases. Results show that after the climate change of 1994, Rkatsiteli showed an advance at higher altitude, the increase of temperature means that the plant spends more time under optimal thermal conditions and, as a consequence, the rate of growth is higher at lower altitudes, and the plant spend more time at over-optimal temperature so that the gorwth is faster than during the old climate but not as fast as it is at higher altitudes.

For instance the average advance of veraison was 5.9 days for $250-500 \mathrm{~m}$ asl belt and 18.1 days for $750-1000 \mathrm{~m}$ asl). On the other hand, at lower altitudes phenological advance was depleted by over-optimal temperatures.

\subsubsection{Ancient climate reconstruction}

A survey carried out in Georgia by Kvavadze and Connor [5] and by Connor and Kvavadze [33] on pollens of Zelkova carpinifolia Pall. highlighted six Holocene climatic optima (the main being located in 6000-5500 BP, 3800-2500 BP and 1350-800 BP). Moreover a survey of lake and lake-swamp sediments in the high mountains of Arkhyz region [49] highlighted an additional three main Holocene climate deteriorations (4300-4200 BP, 1300 1200 BP and 400-350 BP). The sediments of Lake Van - eastern Turkey [50,51] identified four major climatic phases: an arid phase (11000-8200 BP), a phase of gradual increase in rainfall $(8200-6200 \mathrm{BP})$ and a thermalpluviometric optimum $(6000-4000 \mathrm{BP})$ which was closed by an abrupt transition to the present arid conditions. 


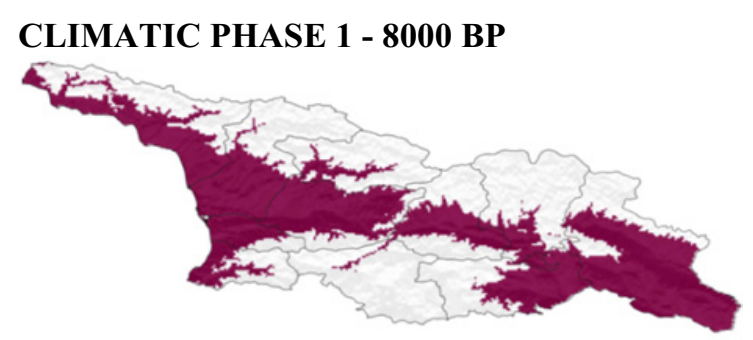

CLIMATIC PHASE 2 - 6700 BP

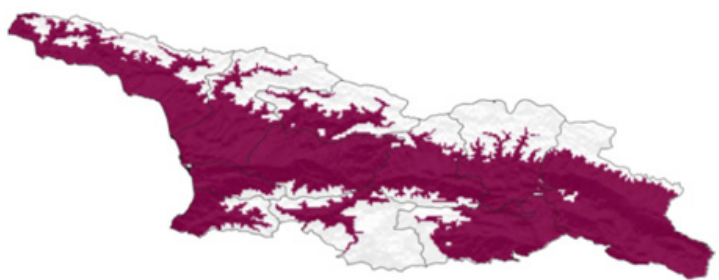

Figures 4, 5. Grapevine suitability (purple area) during first winemaking activity (8000 BP) and pea of the Holocene Climatic Optimum (6700 BP).

The climatic phases shown by the abovementioned studies are the result of macroclimatic changes whose main determinants are alterations in general circulation, probably driven by solar activity and modulated by mesoscale effects. So the abovementioned periodization can be a reasonable baseline for our work which is aimed to define a periodization of the relevant Holocene climate in order to justify the establishment and the evolution of viticulture in Georgia and to explain the migration of the center of gravity of world viticulture from the Caucasia to Europe observed between 6000 and 2000 years BP.

Based on data reported in Figs. 4, 5 and considering Southern aspect (the most favorable for grapevine cultivation), historical maps of potential suitability for vine were determined considering the nine relevant climatic phases:

$1-8000$ B.P. - First winemaking activity in Georgia

2 - 6700 B.P - Peak of the Holocene Climatic Optimum (HCO)

3 - 3400 B.P. - Micenean Climatic Optimum (MCO)

4 - 2900 B.P. - Iron Age Climatic deterioration

5 - 2100 B.P. - Roman Climatic Optimum (RCO)

6 - 1800 B.P. - Climatic deterioration

7 - 900 B.P. - Medieval Warm Period (MWP)

8 - 400 B.P. 0 - Little Ice Age (LIA)

9 - 0 B.P. - Current Warm Period (CWP).

For each period suitability maps were produced. Figs. 4-6 highlight the area of Georgia climatically suitable for viticulture oscillates between $40 \%$ and about the $60 \%$ of the whole territory. Lower values are reached during the cold periods (phases 1,3,4,8) while the higher ones are reached during warm periods (phases 2,5,7,9). During cold phases viticulture back to the plains and low mountains to expand into the higher altitudes during warm phases.

These results were presented on two international conferences in: i) The third International Conference "Phenology 2015" held in Turkey, Kuşadasi, October 5-8, 2015; ii) "Global Worming and Agrobiodiversity" conference held in Tbilisi, November 4-6, 2015.

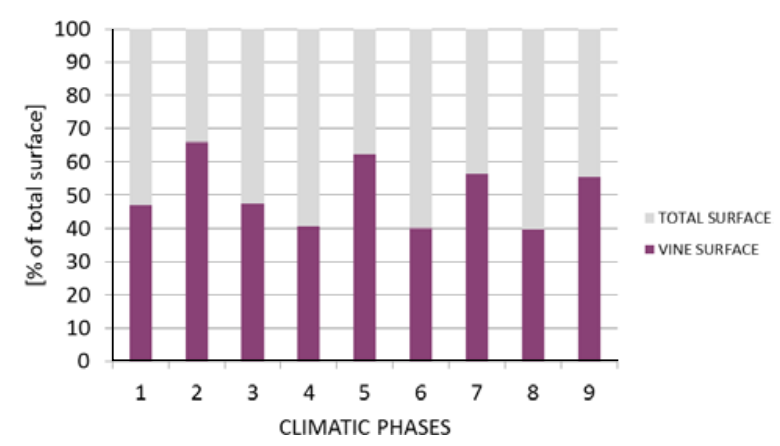

Figure 6. Variation of vine suitable surface in Georgia during the nine climatic phase expressed in percentage of total area.

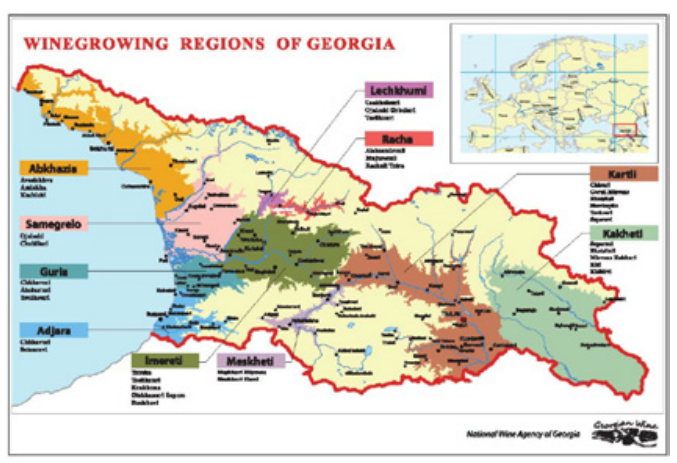

Figure 7. The map of winegrowing regions of Georgia.

\subsubsection{Various aspects of viticulture}

The results of this project have already begun to practical tools for the viticultural industry. An electronic version of a technical handbook has been prepared including agro climatic description of Georgian viticulture with practical recommendation for its management taking in consideration new climatic reality. Information about technical facilities and specialization of wineries and viticultural enterprises has also been collected for the characterization and analyses of wine and viticultural sectors of Georgia.

As a result of the expeditions five new populations of Vitis silvestris in the forest of Sagarejo and Dedoplistskaro districts have been identified and described. The matured woody canes were collected for DNA study, as well as for further propagation in the newly established filed collection repository, in which 98 genotypes of wild Georgian grape varieties have recently been preserved.

Additionally, a map of "The Regions of Viticulture of Georgia" (Fig. 7) and "The Distribution of wild grapevine in Georgia" has been designed. And the National Wine Agency has published a "Reference Book of Georgian Grape Varieties" [52] in the framework of the project.

\subsection{Dissemination and public awareness group}

This final group is tasked with publication and dissemination of these results to a variety of popular and scientific venues.

A manuscript has been prepared for a bilingual book entitled "Grape and Wine Culture of Georgia" by M. Mirvelashvili and D. Maghradze.

"National Geographic Magazine" published an online article by American writer, journalist and traveler Paul Salopek "Ghost of the Vine - In Georgia, science probes 
the roots of winemaking" in English and Georgian languages about our project in 2014. And Andrew Curry is finalizing an article to appear in the January 2017.

With the aim to publicize and underlining the importance of Georgian archaeological and ethnographic heredity of viticulture, as well as the systematization of available information, records for an "Archaeological Catalogue" and "Ethnographic Catalogue" - a total of 610 articles, interviews and photos have been collected. This data was used to prepare a 144 page manuscript entitled "Vines and Wines in Georgia according to archaeological and ethnographic data".

The National Museum of Georgia has organized three public exhibition days for the presentation of the results of the "Gadachrili Gora" archaeological excavations and newly discovered archaeological artifacts to the Mass Media with participation of local authorities such as the Ministry of Culture, Minister of Agriculture, Lower Kartli"s regional administration, Marneuli district's municipality; National Wine Agency and Wine Association and National Museum of Georgia.

Thanks to the joint activity of the experts of National Wine Agency and National Museum of Georgia, a new "Vine and Wine Museum" has been organized at the renewed office of the National Wine Agency in Tbilisi.

\section{Conclusions}

The results obtained in this research initiative demonstrate the effectiveness of the multi-disciplinary approach, as well as the importance of a robust investigation of the deep historical roots and rich diversity of the cultural heritage of the Republic of Georgia, especially as it relates to viti- and viniculture.

\section{References}

[1] D. Zohary, M. Hopf. Domestication of plants in the Old World, 3rd edn. New York: Oxford University Press, 151-159 (2000)

[2] P.E. McGovern. Ancient Wine: The Search for the Origins of Viniculture. Princeton: Princeton University (2007)

[3] L. Bouby, I. Figueiral, A. Bouchette, N. Rovira, S. Ivorra, et al. PLOS ONE, May 2013, 8(5), 1-13 (2013)

[4] N. Rusishvili. Grapevine culture in Georgia on basis of paleobotanical data. 'Mteni Association', ISBN 978-9941-0-2525-9, 37 p. (2010)

[5] L. Wick, G. Lemcke, M. Sturm. Holocene 13, 665-675 (2003)

[6] E. Kvavadze, S. Connor. Review of Palaeobotany and Palynology 133, 69-89 (2005)

[7] O. Japaridze, A. Javakhishvili. The oldest culture for farming of habitants on the territory of Georgia. Tbilisi. 107p. (1971) (in Georgian)

[8] B. Lyonnet, F. Guliyev, L. Bouquet, G. Bruley-Chabot, A. Anaïck Samzun, L. Pecqueur, E. Jovenet, E. Baudouin, M. Fontugne, P. Raymond, E. Degorre, L. Astruc, D. Guilbeau, G. Le Dosseur, N. Benecke, C. Hamon, M. Poulmarc'h, A. Courcier. Quaternary International 395, 170-183 (2016)
[9] C. Hamon, M. Jalabadze, T. Agapishvili, E. Baudouin, I. Koridze, E. Messager 2016. Quaternary International 395, 154-169. (2016)

[10] T. Kighuradze. J. Vazi da Ghvino, 27-29 (2000) (in Georgian)

[11] L. Chilashvili. The vine, wine and the Georgians. Tbilisi. PETITE publisher. (2004)

[12] A. Decaix, E. Messager, M. Tengberg, R. Neef, B. Lyonnet, F. Guliyev. Quaternary International 395, 19-30 (2016)

[13] K. Kh. Kushnareva. The Southern Caucasus in prehistory: stages of cultural and socioeconomic development from the righth to the second Millennium B.C. Tr. H.N. Michael. The University Museum University of Pennsylvania, Philadelphia. (1997)

[14] S.D. Batiuk. J. Anthropological Archaeology 32, 449-477 (2013)

[15] P.E. McGovern. Georgia as homeland of winemaking and viticulture. In: National Treasures of Georgia. O. Z. Soltes. London, P. Wilson and Foundation for International Arts and Education. 58-59. (1999)

[16] I. Javakhishvili. Viticulture. Winemaking. In: Economic history of Georgia. Book 2. Tbilisi (1934) (in Georgian)

[17] N. Ketskhoveli, M. Ramishvili, D. Tabidze. Ampelography of Georgia. Georgian Academy of Sciences, Tbilisi. 439 (1960) (in Georgian and Russian)

[18] G.I. Beridze. Le vins de Georgie. Edition d'Etat "Sabctchota Sakartvelo". Tbilissi. 264p. (1962) (in Georgian and French)

[19] Anonimous. Georgian Agriculture. Statistical Abstracts, Tbilisi (2004) (in Georgian)

[20] D. Maghradze, L. Rustioni, J. Turok, A. Scienza, O. Failla (Eds). Caucasus and Northern Black Sea Region Ampelography. Vitis (special issue). 489p. (2012a)

[21] T. Sharabidze (Ed.). La vigne - l'arbre de vie (La vigne et le vin dans la culture géorgienne). Le recueil. Université d'Etat de Tbilissi Ivané Djavakhishvili. (In Georgian and French) 168p. (2010)

[22] J-F. Terral, E. Tabard, L. Bouby, S. Ivorra, T. Pastor, I. Figueiral, S. Picq, J-B. Chevance, C. Jung, L. Fabre, C. Tardy, M. Compan, R. Bacilieri, T. Lacombe, This P. Annals of Botany 105, 443-455 (2010)

[23] C. Pagnoux, L. Bouby, S. Ivorra, C. Petit, S.M. Valamoti, T. Pastor, S. Picq, J-F. Terral. Vegetation History and Archaeobotany 24, 75-84 (2015)

[24] V. Laucou et al. Theor. Appl. Genet. 122, 1233-1245 (2011)

[25] P.E. McGovern, G.R. Hall, A. Mirzoian. Danish Journal of Archaeology 2, 112-131 (2013a)

[26] P.E. McGovern, B.P. Luley, N. Rovira, A. Mirzoian, M.P. Callahan, K.E. Smith, G.R. Hall, T. Davidson, J.M. Henkin. Proc. Natl. Acad. Sci. USA (PNAS) 110(25), 10147-10152. (2013b)

[27] L. Mariani, S. Parisi, G. Cola, O. Failla. Int. J. Biometeorol. 56, 1123-1134 (2012)

[28] European Environmental Agency, 2016. Global average air temperature anomalies (1850 to 2013) in degrees Celsius $\left({ }^{\circ} \mathrm{C}\right)$ relative to a pre-industrial 
baseline period, http://www.eea.europa.eu/ data-and-maps/figures/global-annualaverage-temperature-deviations-1850-2007relative-to-the-1850-1899-average-in-octhe-lines-refer-to-10-year-movingaverage-the-bars-to-the-annual-landand-ocean-global-average-9. (Accessed 15 August 2016)

[29] L. Rustioni, D. Maghradze, C.F. Popescu, et al. Vitis 53, 219-226 (2014a)

[30] L. Rustioni, G. Cola, S. Fiori, et al. Acta Hortic. 1032: 253-260 (2014b)

[31] L. Mariani, R. Alilla, G. Cola, G. Dal Monte, C. Epifani, G. Puppi, O. Failla. Int. J. Biometeorol. DOI 10.10007/s00484-012-0615-x: 1-13 (2013)

[32] D. Maghradze, L. Rustioni, A. Scienza, O. Failla. J. Amer. Pom. Soc. 66(2), 56-67 (2012b)

[33] S.E. Connor, E.V. Kvavadze. J. Biogeogr. 36, 529-545 (2008)

[34] M. Rosch. Veg. Hist. Archaeobot, 14, 179-188 (2005)

[35] E. Kvavadze, M. Chichinadze, I. Martkoplishvili. Proceedings of 33-rd World Congress of Vine and Wine, 8-th General Assembly of the OIV, 20-25 June 2010, Tbilisi, Georgia (2010a)

[36] E. Kvavadze, M. Jalabadze, N. Shakulashvili. Proceedings of 33-rd World Congress of Vine and Wine, 8-th General Assembly of the OIV, 20-25 June 2010, Tbilisi, Georgia (2010b)

[37] S.D. Turnen, A.G. Brown. Review of Palaeobotany and Palynology, 129, 117-132 (2004)

[38] E. Kvavadze. Abstracts of 5-th International Meeting of Pollen Monitoring Programme. Varna (Bulgaria). $14(2005)$

[39] E. Kvavadze, M. Chichinadze. Proceedings of the 6-th International Meeting of Pollen Monitoring Programme, Riga, 2007. 45-47 (2007)
[40] M. Jalabadze, K. Esakia, N. Rusishvili, E. Kvavadze, I. Koridze, N. Shakulashvili, M. Tsereteli. Dziebani - Journal of the Georgian Archaeology 18, 17-32 (2010) (in Georgian)

[41] E. Kvavadze, M. Jalabadze, I. Koridze, N. Rusishvili, M. Chichinadze, I. Martkoplishvili. Proceedings of Natural and Prehistoric Section 6, 42-57 (2014) (in Georgian)

[42] L. Stuclik, E. Kvavadze. Acta Palaeobot. 38(1), 217-222 (1998)

[43] E. Kvavadze, L. Stuchlik. Acta Palaeobot. 36(1), 121-147 (1996)

[44] E. Kvavadze, M. Chichinadze, I. Martkoplishvili. Abstracts of 10-th Pollen Monitoring Programme Conference, 20-21p., Istambul 12-16 May 2015 (2015)

[45] E.V. Kvavadze, L. Stuchlik. Acta Palaeobot. 33(1), 365-376 (1993)

[46] G. De Lorenzis, R. Chipashvili, O. Failla, D. Maghradze. BMC Plant Biology 15, 154 (2015)

[47] P.E. McGovern, M.M. Voigt, D.L. Glusker, L.J. Exner. Nature 381(6), 480-481 (1996)

[48] G. Cola, O. Failla, D. Maghradze, L. Meghrelidze, L. Mariani, 2016. Int. J. of Biometeorology (accepted)

[49] E. Kvavadze, Y.V. Efrimov. Acta Paleobot. 36, 107-119 (1996)

[50] G. Lemcke, M. Sturm. $\delta^{18} \mathrm{O}$ and Trace Element Measurements as Proxy for the Reconstruction of Climate Changes at Lake Van (Turkey): Preliminary Results, in: Dalfes N., Kukla G., Weiss H. (eds). Third Millennium BC Climate Change and Old World Collapse. Berlin, Springer, 653-678 (1997)

[51] L. Wick, G. Lemcke, M. Sturm. Holocene 13, 665-675 (2003)

[52] T. Kobaidze. Reference book for Georgian local varieties. Publisher: National Wine Agency. Tbilisi. 168p. (2014) (in Georgian) 